\title{
Specific 1,25-Hydroxycholecalciferol Receptors and Stimulation of 25-Hydroxycholecalciferol- 24R Hydroxylase in Human Amniotic Cells
}

\author{
EDGARD E. DELVIN, ANNE-MARIE PILON, AND MICHEL VEKEMANS \\ Genetics Unit, Shriners Hospital [E.E.D., A-M.P.], Departments of Experimental and Pediatrics, McGill \\ University [E.E.D.], McGill Prenatal Diagnosis Unit, Montreal Children's Hospital, and Department of Pediatric \\ Pathology, McGill University [M.V.], Montreal, Canada
}

\begin{abstract}
We have analyzed the 1 $\alpha, 25$-dihydroxycholecalciferol $\left[1,25(\mathrm{OH})_{2} \mathrm{D}_{3}\right]$ receptor content of cultured cells from human amniotic fluid. Six cell lines were grown to confluence in a minimum essential medium containing $20 \%$ fetal calf serum. All had a normal karyotype, five were male and one was female. Hypertonic cytosol extracts were prepared by sonication followed by centrifugation at $200,000 \times g 30 \mathrm{~min}$. Saturation analysis was performed by incubating the extracts with $\left[{ }^{3} \mathrm{H}\right]-1,25(\mathrm{OH})_{2} \mathrm{D}_{3}(20-500$ pM, $160 \mathrm{Ci} / \mathrm{mmol}$ ) with and without 100 -fold molar excess of unlabeled $1,25(\mathrm{OH})_{2} \mathrm{D}_{3}$. Linear sucrose gradient $(5$ $20 \% \mathrm{w} / \mathrm{v})$ analysis was performed with $1.5 \mathrm{nM}\left[{ }^{3} \mathrm{H}\right]-$ $1,25(\mathrm{OH})_{2} \mathrm{D}_{3}$ alone or in presence of 100 -fold molar excess, $1,25(\mathrm{OH})_{2} \mathrm{D}_{3}$. Functional responsiveness was measured by induction of 25-hydroxycholecalciferol-24R-hydroxylase with 1 and $10 \mathrm{nM} 1,25(\mathrm{OH})_{2} \mathrm{D}_{3}$. The six cell lines studied had receptors with dissociation constant of $44 \pm 6 \mathrm{pM}$ (mean \pm SEM). The binding capacity was 10,200 $\pm 1,750$ sites/ng protein (mean \pm SEM) with extreme values of 4,700 and 15,500. A single peak for specific binding migrating at approximately $3 \mathrm{~S}$ was observed by sucrose gradient centrifugation. 25-Hydroxycholecalciferol-24R-hydroxylase was induced by 1 and $10 \mathrm{nM} 1,25(\mathrm{OH})_{2} \mathrm{D}_{3}$ in a dose-dependent fashion. The data show that receptors for $1,25(\mathrm{OH})_{2} \mathrm{D}_{3}$ are present in cultured amniotic fibroblastlike cells early in pregnancy. These cells may thus prove to be useful for further characterization of $1,25(\mathrm{OH})_{2} \mathrm{D}_{3}$ receptors in fetal tissue. (Pediatr Res 21: 432-435, 1987)
\end{abstract}

Abbreviations

$1,25(\mathrm{OH})_{2} \mathrm{D}_{3}, 1 \alpha, 25$-dihydroxycholecalciferol $24,25(\mathrm{OH})_{2} \mathrm{D}_{3}, 24 \mathrm{R}, 25$-dihydroxycholecalciferol

$25,26(\mathrm{OH})_{2} \mathrm{D}_{3}, 25,26$-dihydroxycholecalciferol

25- $\mathrm{OHD}_{3}, 25$-hydroxycholecalciferol

24-OHase, 25-hydroxycholecalciferol-24R-hydroxylase

MEM, minimum essential medium

BSA, bovine serum albumin

HEPES, N-2-hydroxyethylpiperazine- $\mathrm{N}^{1}$-2-ethanesulphonic acid

HPLC, high-performance liquid chromatography

DTT, reduced dithiothreitol

Kd, dissociation constants

$\beta$ max, maximal binding capacity

Received August 18, 1986; accepted December 4, 1986

Correspondence and address for reprint requests to Edgard E. Delvin, Shriners

Hospital, Genetics Unit, Montreal, Canada, H3G 1A6.

Supported by the Shriners of North America.
Previous reports have shown that rat, murine, and human skin and cultured fibroblasts possessed an effector system for $1,25(\mathrm{OH})_{2} \mathrm{D}_{3}(1-5)$ suggesting that these tissues could serve as targets for the hormonal form of vitamin $\mathrm{D}_{3}$. Moreover, it has been established that these cells were responsive to $1,25(\mathrm{OH})_{2} \mathrm{D}_{3}$ by showing an unequivocal stimulation of 24-OHase $(6,7)$.

In addition to their use in prenatal diagnosis of genetic disorders, midgestation amniotic fluid cells are ready sources for studies on developmental biology. Epithelia, such as amniotic membranes, fetal epidermis, and the mucosa of the digestive, respiratory or urogenital tract are potential sources of these cells. They thus provide morphologically and biochemically distinct fetal cells that are isogenic (8). Upon culture some of these cells acquire a morphology resembling that of skin fibroblasts (9). Although these cells show small differences in protein fingerprinting (10), they have been used for the prenatal diagnosis of hormonal disorders $(11-13)$. The present study therefore was designed to ascertain whether specific receptors for $1,25(\mathrm{OH})_{2} \mathrm{D}_{3}$ are present in cultured amniotic fluid fibroblast-like cells and whether these cells are responsive to $1,25(\mathrm{OH})_{2} \mathrm{D}_{3}$.

\section{MATERIALS AND METHODS}

Materials. MEM with Earle's salts, penicillin, streptomycin, pyruvic acid (Na salt), Puck's N-15 medium, and Puck's saline solution were all obtained from GIBCO Canada (Burlington, Ontario, Canada). Newborn bovine and fetal calf sera were purchased from Flow Laboratories (Mississauga, Ontario, Canada). Trypsin was from Difco Laboratories (Detroit, MI). Dithiothreitol (Cleland's reagent), Triton X-100, Tris-HCl, HEPES, and BSA (RIA grade) were obtained from Sigma Chemical Co. (St. Louis, MO); hydroxylapatite (Bio-Gel HTP), silicic acid (325 mesh) were from Bio-Rad Laboratories (Mississauga, Ont., Canada). Trasylol was purchased from Boehringer-Mannheim Canada; Dextran T-20 from Pharmacia Canada; ${ }^{14} \mathrm{C}$-albumin, ${ }^{14} \mathrm{C}$ ovalbumin and Aquasol from New England Nuclear (Montreal, Quebec, Canada). The purity of 25-hydroxy-[26,27-methyl- $\left.{ }^{3} \mathrm{H}\right]$ cholecalciferol $\left({ }^{3} \mathrm{H}-25 \mathrm{OHD}_{3}, 20 \mathrm{Ci} / \mathrm{mmol}\right)$ and of $1 \alpha, 25$-dihydroxy-[26,27-methyl- $\left.{ }^{3} \mathrm{H}\right]$ cholecalciferol $\left[{ }^{3} \mathrm{H}-1,25(\mathrm{OH})_{2} \mathrm{D}_{3}, 150-\right.$ $180 \mathrm{Ci} / \mathrm{mmole}$, from Amersham (Oakville, Ontario, Canada), was verified by $\mathrm{HPLC}(14)$. Crystalline $25 \mathrm{OHD}_{3}, 1,25(\mathrm{OH})_{2} \mathrm{D}_{3}$, $24,25(\mathrm{OH})_{2} \mathrm{D}_{3}$, and $25,26(\mathrm{OH})_{2} \mathrm{D}_{3}$ were kindly given by $\mathrm{Dr}$. Milan R. Uskokovic from Hoffman-LaRoche (Nutley, NJ). All solvents were of HPLC grade.

Cell culture. Six amniotic fluid samples (15 to $20 \mathrm{ml}$ ) obtained by transabdominal amniocentesis from women in their 15 th to 17 th wk of gestation were sent to the laboratory under sterile conditions. Cultures were established within $4 \mathrm{~h}$ of sampling. Samples were centrifuged at $800 \times g$ for $10 \mathrm{~min}$ and the cells suspended in MEM supplemented with $20 \%$ FCS, 2 mM gluta- 
mine, streptomycin $(50 \mu \mathrm{g} / \mathrm{ml})$, and penicillin $(50 \mathrm{IU} / \mathrm{ml})$. Cells were cultured at $37^{\circ} \mathrm{C}$ in a controlled humidified atmosphere (5\% $\mathrm{CO}_{2} / 95 \%$ air). Medium was replaced every other day until the first harvesting for chromosome analysis. Subcultures were established in MEM supplemented with $6 \%$ fetal calf serum, $6 \%$ newborn bovine serum, $2 \mathrm{mM}$ glutamine, streptomycin $(10 \mu \mathrm{g} /$ $\mathrm{ml})$, and penicillin $(10 \mathrm{IU} / \mathrm{ml})$.

Chromosome analysis. Colcemid $(1 \mu \mathrm{g} / \mathrm{ml})$ was added to the culture medium $16-24 \mathrm{~h}$ prior to harvesting by trypsinization. The cells were lysed with hypotonic phosphate buffer at $\mathrm{pH} 7.4$ for $15 \mathrm{~min}$. They were fixed with a solution of methanol-acetic acid $(3 / 1)$ for $20 \mathrm{~min}$. This step was repeated once before the chromosomes were processed for GTG banding (15). All six cultures were karyotypically normal. Five were male and one was female.

Cytosol receptor assay. For each assay, cells were grown to confluence in three Falcon T150 flasks. They were incubated for two consecutive $1-\mathrm{h}$ periods in serum-free medium before being detached with $0.05 \%$ trypsin, $0.02 \%$ EDTA in buffered saline at $37^{\circ} \mathrm{C}$. All steps were henceforth carried at $4^{\circ} \mathrm{C}$ unless otherwise indicated. The suspended cells were washed twice in serum-free medium by gentle suspension and centrifugation $(200 \times g 10$ min). They were suspended in $3 \mathrm{ml}$ of buffer A consisting of $0.01 \mathrm{M}$ Tris- $\mathrm{HCl}$, pH 7.4, $0.01 \mathrm{M} \mathrm{Na}_{2} \mathrm{MoO}_{4}, 1.5 \mathrm{mM}$ EDTA, $0.5 \mathrm{mM}$ DTT, Trasylol (500 kallikrein inactivator $\mathrm{U} / \mathrm{ml}$ ), and $0.3 \mathrm{M} \mathrm{KCl}$. Cells were then disrupted by sonication (four bursts of $2 \mathrm{~S}$ each). Debris were pelleted at $2 \times 10^{5} \mathrm{~g}$ for $1 \mathrm{~h}$ in a SW50 Ti rotor (Beckman Instruments, Palo Alto, CA). The supernatant was diluted so as to have $1-2 \mathrm{mg}$ protein $/ \mathrm{ml}$. The receptor assay was performed according to the method of Feldman et al. (3). The Kd and the maximum binding capacities were estimated by the Woolf plot analysis (16). Proteins were measured according to the method of Lowry et al. (17) using BSA as standard.

Linear sucrose density gradient analysis. Cells were grown, harvested and sonicated as for the receptor assays except that the concentration of protein was adjusted at $5-10 \mathrm{mg} / \mathrm{ml}$. Incubations were carried out for 16 hours at $4^{\circ} \mathrm{C}$ with $200 \mu \mathrm{l}$ of cytosol extract in presence of $1.5 \mathrm{nM}$ labeled $1,25(\mathrm{OH})_{2} \mathrm{D}_{3}$ with and without 100 -fold excess of either unlabeled $1,25(\mathrm{OH})_{2} \mathrm{D}_{3}$, $24,25(\mathrm{OH})_{2} \mathrm{D}_{3}$ or $25-\mathrm{OHD}_{3}$. Unbound steroids were removed with dextran-coated charcoal (19). The cell extracts were layered on top of a linear $5-20 \%$ sucrose gradient in buffer A. Reference proteins, ${ }^{14} \mathrm{C}$-albumin and ${ }^{14} \mathrm{C}$-ovalbumin, were centrifuged simultaneously. Centrifugation was performed at $4^{\circ} \mathrm{C}$ for 16 hours at $225,000 \mathrm{~g}$ in a L8-M ultracentrifuge with the SW-50 Ti swinging bucket rotor (Beckman Instruments, Palo Alto, CA). The gradients were layered and collected using the Buchler AutoDensi Flow IIC pump (Buchler Instruments, Fort Lee, NJ).

24-OHase. The assay was performed essentially as described by Griffin and Zerwekh et al. (6) for skin fibroblasts. Confluent cultures in T-75 flasks were rinsed twice with MEM medium containing $1 \%$ serum. Unlabeled $1,25(\mathrm{OH})_{2} \mathrm{D}_{3}(1$ and $10 \mathrm{nM})$ in $95 \%$ ethanol was added in separate flasks. Control flasks contained the vehicle only. The final concentration of ethanol was $0.2 \%$. The incubations were carried under a controlled $95 \%$ air$5 \% \mathrm{CO}_{2}$ atmosphere at $37^{\circ} \mathrm{C}$ for $16 \mathrm{~h}$. Cells were then rinsed twice with serum-free medium, freed from the dish with trypsin, carefully rinsed twice, and suspended in $500 \mu \mathrm{l}$ of medium containing $1 \%$ newborn calf serum. Aliquots $(200 \mu 1)$ of the cell suspensions were incubated for $30 \mathrm{~min}$ at $37^{\circ} \mathrm{C}$ in screw cap Pyrex tubes in presence of $0.5 \mu \mathrm{M}$ 25-hydroxy-[26,27-methyl ${ }^{3} \mathrm{H}$-cholecalciferol adjusted at $1 \mathrm{Ci} / \mathrm{mmol}$ with unlabeled 25 $\mathrm{OHD}_{3}$. Blanks consisted of cells boiled for $30 \mathrm{~min}$ and incubated in identical conditions. The reaction was stopped by the addition of $300 \mu \mathrm{l}$ of medium with $1 \%$ serum and $2 \mathrm{ml}$ of anhydrous diethylether. Extractions and purification were performed as described by Delvin et al. (19). In brief, cells and medium were extracted three times with anhydrous diethylether kept on ferrous sulfate. The combined extracts were evaporated to dryness under a stream of nitrogen, redissolved in $50 \%$ diethylether in $n$-hexane, and purified by column chromatography. Short $(0.5 \times 4 \mathrm{~cm})$ silicic acid ( $<325$ mesh) columns were washed and equilibrated with $50 \%$ ether in $n$-hexane. Samples were applied in a $1-\mathrm{ml}$ volume. Elution was started by sequentially washing the columns with $3 \mathrm{ml}$ of each of the following: $50 \%$ diethylether in $n$-hexane, $80 \%$ diethylether in $n$-hexane, and $20 \%$ acetone in diethylether. To assess the recovery of the labeled material, columns were stripped with $3 \mathrm{ml}$ of methanol. The fraction $(20 \%$ acetonediethylether) containing the polar metabolites was further purified by high performance liquid chromatography on a $5 \mu \mathrm{m}$ Lichosorb Si-60 HIBAR-II column $(4.6 \times 250 \mathrm{~mm}$; E. Merk, Darmstadt, West Germany) equilibrated with $6 \%$ propan-2-ol in $n$-hexane. HPLC fractions were counted in a refrigerated LKB 1219 (Wallac, Bromma, Sweden).

\section{RESULTS}

Representative plots for total, nonspecific, and saturable calculated specific binding of labeled $1 \alpha, 25(\mathrm{OH})_{2} \mathrm{D}_{3}$ are shown in Figure $1 A$. In all experiments the nonspecific binding, obtained in presence of excess radioinert hormone, averaged $15 \%$ of the total binding. Woolf analysis of the specific binding data is shown in Figure $1 B$. These data, which fit a first order regression analysis, suggest the presence of a single class of high affinity receptors $1 \alpha, 25(\mathrm{OH})_{2} \mathrm{D}_{3}$ in hypertonic cytosolic extracts. Table 1 lists the individual values for the apparent $\mathrm{Kd}$ and $\beta$ max. Whereas the distribution of the former is relatively narrow (22$62 \mathrm{pM}$ ) with a mean \pm SEM of $39 \pm 9 \mathrm{pM}$, the maximal number of sites, expressed as the number of molecules of $1,25(\mathrm{OH})_{2} \mathrm{D}_{3}$ bound/ng protein varied from 4,697 to 15,528 (mean 10,444 \pm 1,492 ). Similar results were obtained when the Scatchard analysis (20) was used (data not shown). Although individual points were
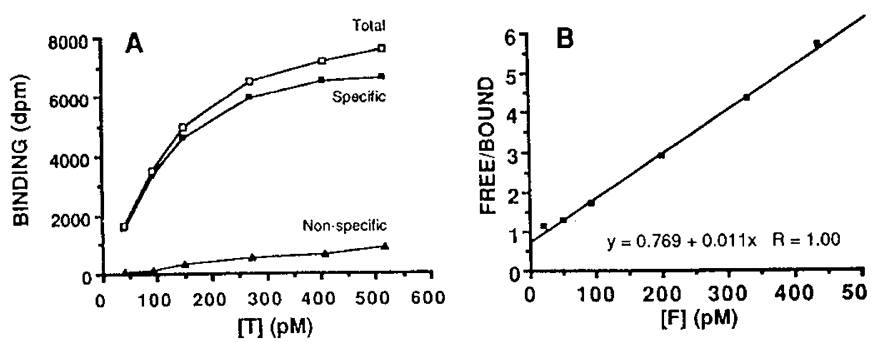

Fig. 1. Saturation analysis of $1 \alpha, 25(\mathrm{OH})_{2} \mathrm{D}_{3}$ binding by hypertonic cytosolic extracts of confluent amniotic fluid cells. The extracts, prepared as described in "Materials and methods," were incubated for $16 \mathrm{~h}$ at $4^{\circ}$ $\mathrm{C}$ with increasing concentrations of $1 \alpha, 25$-dihydroxy-[26,27-methyl$\left.{ }^{3} \mathrm{H}\right]$-cholecalciferol in the presence or absence of a 100 -fold molar excess of radioinert $1 \alpha, 25(\mathrm{OH})_{2} \mathrm{D}_{3}$. Free sterol was removed with dextran-coated charcoal. $A$, specific binding as the difference between the total and the nonspecific binding; $B$, Woolf plot (15) of the specific binding $(r=$ 0.999).

Table 1. Binding characteristics of cultured amniotic fluid cells $1,25(\mathrm{OH})_{2} D_{3}$ receptors*

\begin{tabular}{ccccc}
$\begin{array}{c}\text { Cell strain } \\
\text { no. }\end{array}$ & $\begin{array}{c}\text { wk of } \\
\text { gestation }\end{array}$ & Karyotype & $\begin{array}{c}\text { Kd } \\
(\mathrm{pM})\end{array}$ & $\begin{array}{c}\beta \text { max } \\
(\text { mol/ng protein })\end{array}$ \\
\hline 1 & 15.5 & $46 \mathrm{XY}$ & 62 & 15528 \\
2 & 16.0 & $46 \mathrm{XX}$ & 31 & 13935 \\
3 & 16.5 & $46 \mathrm{XY}$ & 38 & 9660 \\
4 & 15.0 & $46 \mathrm{XY}$ & 60 & 11213 \\
5 & 16.5 & $46 \mathrm{XY}$ & 48 & 4697 \\
6 & 16.0 & $46 \mathrm{XY}$ & 22 & 7632 \\
Mean \pm SEM & & & $39 \pm 9$ & $10444 \pm 1492$ \\
\hline
\end{tabular}

* The $\mathrm{Kd}$ and the $\beta$ max were determined by Woolf analysis. 
more dispersed, when interpreted in this fashion, in all cases the data fitted a first-order regression analysis. Linear sucrose density-gradient analysis of the hypertonic extracts revealed a single peak of bound $1,25(\mathrm{OH})_{2} \mathrm{D}_{3}$ sedimenting at approximately $3 \mathrm{~S}$ (Fig. 2A). This binding was completely abolished with 100 -fold molar excess of radioinert $1 \alpha 25(\mathrm{OH})_{2} \mathrm{D}_{3}$ level (Fig. $2 \mathrm{C}$ ). The radioactive ligand was only partially displaced by the same molar concentration either of $24,25(\mathrm{OH})_{2} \mathrm{D}_{3}$ or $25-\mathrm{OHD}_{3}$ (Fig. $2 B$ and $D)$. The bioresponse of the amniotic fluid cells was assessed in separate experiments by determining the ability of $1,25(\mathrm{OH})_{2} \mathrm{D}_{3}$ to induce a $25-\mathrm{OHD}_{3}$ metabolism to presumably $24,25(\mathrm{OH})_{2} \mathrm{D}_{3}$. Cells stimulated overnight either with 1 or $10 \mathrm{nM} 1,25(\mathrm{OH})_{2} \mathrm{D}_{3}$ produced, in a dose-response fashion, a compound that coeluted with crystalline $24,25(\mathrm{OH})_{2} \mathrm{D}_{3}$ on a Lichrosorb Si-60 column using straight phase chromatography (Fig. $3 C$ and $D$ ). Unstimulated cells produced a small amount of this product (Fig. $3 B$ ). No labeled material could be elicited in blanks using boiled cells (Fig. 3A).

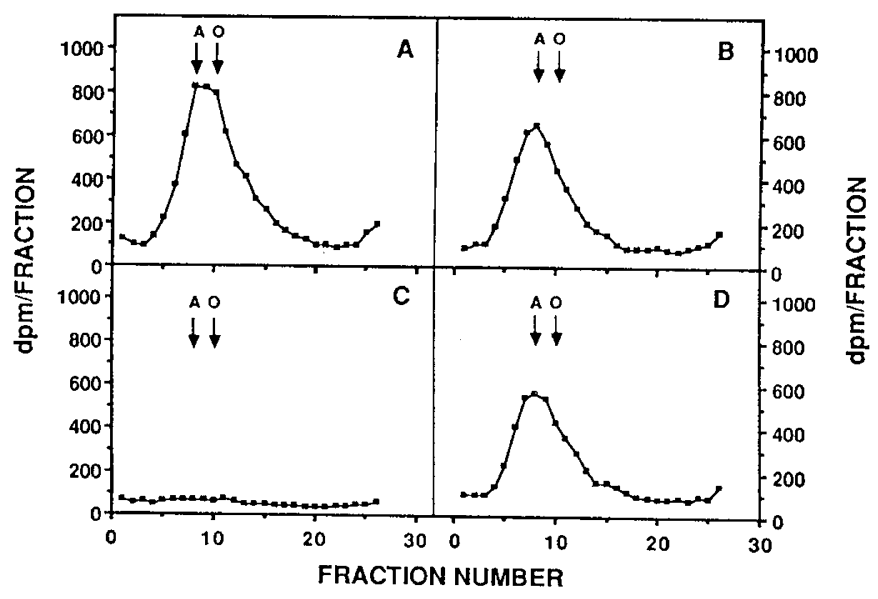

Fig. 2. Sucrose gradient analysis of $1 \alpha, 25$-dihydroxy-[26,27-methyl$\left.{ }^{3} \mathrm{H}\right]$-cholecalciferol binding in cytosolic extracts. Incubations were done in presence of $1.5 \mathrm{nM}$ labeled $1,25(\mathrm{OH})_{2} \mathrm{D}_{3}$ alone $(A)$, or in presence of 100 -fold molar excess either of radio inert $24,25(\mathrm{OH})_{2} \mathrm{D}_{3}(B)$; $\left.1, \alpha 25(\mathrm{OH})_{2} \mathrm{D}_{3}\right)(C)$; or $25-\mathrm{OHD}_{3}(D)$. Four drop fractions were collected, from top to bottom of the gradient, directly into scintillation vials for counting. The arrows indicate the position of ${ }^{14} \mathrm{C}$-albumin $(3.0 \mathrm{~S})$ and ${ }^{14} \mathrm{C}$-ovalbumin (3.6 S) run in parallel gradients.

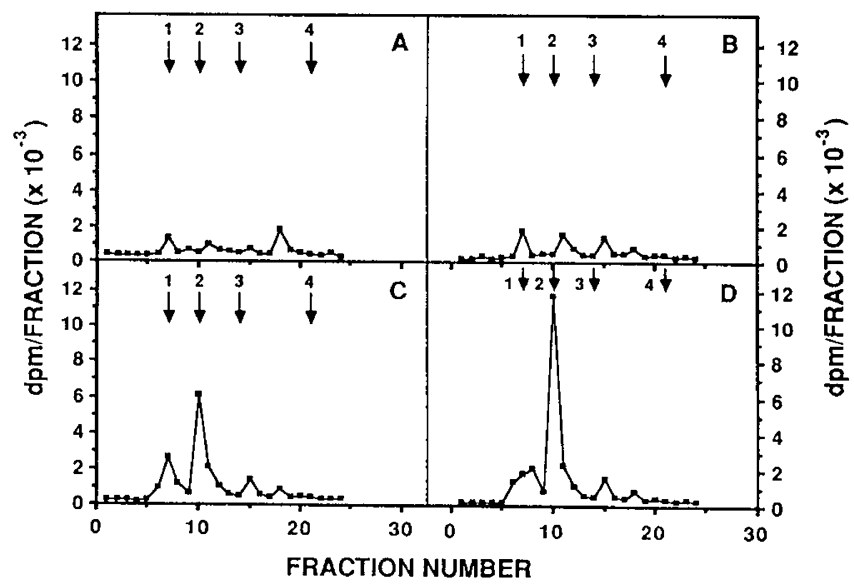

Fig. 3. HPLC elution patterns of the radioactivity extracted from cultured amniotic fluid cells and medium. Confluent cells were treated, overnight, either with $1 \alpha, 25(\mathrm{OH})_{2} \mathrm{D}_{3}$ or the vehicle only (ethanol) as described in "Materials and methods." Arrows indicate the position of the reference vitamin $\mathrm{D}_{3}$ metabolites: 1) $\left.25-\mathrm{OHD}_{3}, 2\right) 24,25(\mathrm{OH})_{2} \mathrm{D}_{3}, 3$ ) $\left.25,26(\mathrm{OH})_{2} \mathrm{D}_{3}, 4\right) 1 \alpha, 25(\mathrm{OH})_{2} \mathrm{D}_{3}$. $A$, blank 1 (boiled cells); $B$, blank 2 (vehicle only); $\left.C, 1 \mathrm{nM} 1 \alpha, 25(\mathrm{OH})_{2} \mathrm{D}_{3} ; \mathrm{D}\right) 10 \mathrm{nM} 1 \alpha, 25(\mathrm{OH})_{2} \mathrm{D}_{3}$.

\section{DISCUSSION}

The findings presented in this report demonstrate the presence of specific $1,25(\mathrm{OH})_{2} \mathrm{D}_{3}$ receptors in cultured amniotic fibroblastlike cells early in pregnancy. These receptors exhibit, under equilibrium conditions, $\mathrm{Kd}$ properties similar to those observed for cultured skin fibroblasts $(7,21)$ and for other target tissues in different species $(22,23)$. Despite differences in cell extract preparation and protein measurement methods among investigators, the estimated maximal binding capacities are of the same order of magnitude as those reported by others for serially cultured dermal fibroblasts $(3,5,21)$. The number of binding sites varied widely from one cell strain to another. We believe this to truly reflect a biological heterogeneity as growth phase of the cultures, a factor reported to influence binding characteristics (24) is the same for the six cell strains studied. Moreover as the data obtained from each individual cell line fitted a first order regression analysis only one high affinity class of receptors are probably present. A single peak with binding activity is observed upon sucrose-gradient analysis of the hypertonic cytosolic extract. Its sedimentation coefficient is in agreement with those reported by others in either cultured skin fibroblasts $(3,5)$ or in other target tissues $(22,25)$. The specificity of this macromolecule for $1,25(\mathrm{OH})_{2} \mathrm{D}_{3}$ is evident as incubation of the extracts in presence of 100 -fold excess of unlabeled $1,25(\mathrm{OH})_{2} \mathrm{D}_{3}$ completely abolishes the 3.0-3.6 S peak of radioactivity. Furthermore no displacement of ${ }^{3} \mathrm{H}-1,25(\mathrm{OH})_{2} \mathrm{D}_{3}$ is observed when extracts are incubated with a 100 -fold excess of either radioinert $25-\mathrm{OHD}_{3}$ or $24,25(\mathrm{OH})_{2} \mathrm{D}_{3}$.

Since the induction of 24-OHase is recognized as an adequate marker for postreceptor $1,25(\mathrm{OH})_{2} \mathrm{D}_{3}$ action $(6,7,26,27)$, our results also show that these cells already have the regulatory mechanisms present in differentiated tissues. Whether these findings which combine receptor binding data with sedimentation and an in vitro functional test reflect the responsiveness of other fetal target tissues, remains to be elucidated. However, it is interesting to note that $1,25(\mathrm{OH})_{2} \mathrm{D}_{3}$ receptors have been shown in fetal rat bone and small intestine (28). Therefore one may assume that such receptors are also present in other human target tissues. In conclusion, our data provide evidence that early in pregnancy amniotic fluid fibroblast-like cells possess specific $1,25(\mathrm{OH})_{2} \mathrm{D}_{3}$.

Acknowledgments. The authors thank H. Scarpelli for her technical assistance, Farla Miller for preparation of the manuscript, and Mark Lepik for the illustrations.

\section{REFERENCES}

1. Simpson RU, DeLuca HF 1980 Characterization of a receptor-like protein for 1,25-dihydroxyvitamin $D_{3}$ in rat skin. Proc Natl Acad Sci USA 77:58225826

2. Clemens TL, Horiuchi N, Nguyen M, Holick MF 1981 Binding of 1,25dihydroxy- $\left[{ }^{3} \mathrm{H}\right]$ vitamin $\mathrm{D}_{3}$ in nuclear and cytosol fractions of whole mouse skin in vivo and in vitro. FEBS Lett 134:203-206

3. Feldman D, Chen T, Hirst M, Colston K, Karasek M, Cone C 1980 Demonstration of 1,25-dihydroxyvitamin $\mathrm{D}_{3}$ receptors in human skin biopsies. J Clin Endocrinol Metab 51:1463-1465

4. Eil C, Marx SJ 1981 Nuclear uptake of $\left[{ }^{3} \mathrm{H}\right] 1,25$-dihydroxycholecalciferol in dispersed fibroblasts cultured from human skin. Proc Natl Acad Sci USA $78: 2562-2566$

5. Clemens TL, Adams JS, Horiuchi N, Gilchrest BA, Cho H, Tsuchiya Y, Matsuo N, Suda T, Holick MF 1983 Interaction of 1,25-dihydroxyvitamin$D_{3}$ with keratinocytes and fibroblasts from skin of normal subjects and subjects with vitamin-D-dependent rickets, type II: a model for study of the mode of action of 1,25-dihydroxyvitamin $D_{3}$. J Clin Endocrinol Metab 56:824-830

6. Griffin JE, Zerwekh JE 1983 Impaired stimulation of 25-hydroxyvitamin D24-hydroxylase in fibroblasts from a patient with vitamin D-dependent rickets, type II. J Clin Invest 72:1190-1199

7. Chen TL, Hurst MA, Cone CM, Hochberg Z, Tietze H-U, Feldman D 1984 1,25-dihydroxyvitamin $\mathrm{D}$ resistance, rickets and alopecia: analysis of receptors and bio-response in cultured fibroblasts from patients and parents. J Clin Endocrinol Metab 59:383-388

8. Virtanen I, von Koskull H, Lehto VP, Vartio T, Aula P 1981 Cultured human amniotic fluid cells characterized with antibody against intermediate filaments in direct immunofluorescence microscopy. J Clin Invest 68:13481355 
9. Hoehn H, Bryant EM, Karp LE, Martin GM 1974 Cultivated cells from diagnostic amniocentesis in second trimester pregnancies. 1. Clonal morphology and growth potential. Pediatr Res 8:746-754

10. Johnston P, Salk D, Martin GM, Hoehn H 1982 Cultivated cells from midtrimester amniotic fluids: IV, cell type identification via one and twodimensional electrophoresis of clonal whole cell homogenates. Prenat Diagn $2: 79-88$

11. Milunsky A 1976 Current concepts in genetics: prenatal diagnosis of growth disorders. N Engl J Med 295:377-380

12. Sultan C, Migeon BR, Rothwell SW, Maes M, Zerhouni N, Migeon CJ 1980 Androgen receptors and metabolism in cultured human fetal fibroblasts. Pediatr Res 14:67-69

13. Sultan C, Emberger JM, Devillier C, Clavis C, Terraza A, Descomps B, Jean R 1984 Specific $5 \alpha$-dihydrotesterone receptor and $5 \alpha$-reductase activity in amniotic fluid cells. Am J Obstet Gynecol 150:956-960

14. Jones G, DeLuca HF 1975 High pressure liquid chromatography: Separation of the metabolites of vitamin $D_{2}$ and $D_{3}$ on small particle silica columns. J Lipid Res 16:448-453

15. Seabright $M 1971$ A rapid banding technique for human chromosomes. Lancet 2:971-972

16. Keightley DD, Cressie NAC 1980 The Woolf plot is more reliable than the Scatchard plot in analysing data from hormone receptor assays. J Steroid Biochem 13:1317-1232

17. Lowry OH, Rosebrough NJ, Farr AL, Randall RJ 1951 Protein measurement with the Folin phenol reagent. J Biol Chem 193:265-275

18. Delvin EE, Glorieux FH 1981 Serum 1,25-dihydroxyvitamin D concentration in hypophosphatemic vitamin D-resistant rickets. Calcif Tissue Int 33:173175

19. Delvin EE, Arabian A, Glorieux FH, Mamer OA 1985 In vitro metabolism of 25-hydroxycholecalciferol by isolated cells from human decidua. J Clin
Endocrinol Metab 60:880-885

20. Scatchard G 1949 The attractions of proteins for small molecules and ions Ann NY Acad Sci 51:660-672

21. Hirst MA, Hochman HI, Feldman D 1985 Vitamin D resistance and alopecia: a kindred with normal 1,25-dihydroxyvitamin $\mathrm{D}$ binding, but decreased receptor affinity for deoxyribonucleic acid. J Clin Endocrinol Metab 60:490495

22. Wecksler WR, Norman AW 1980 Biochemical properties of $1 \alpha, 25$-dihydroxyvitamin D receptors. J Steroid Biochem 13:977-989

23. Duncan WE, Walsh PG, Kowalski MA, Haddad JG 1985 Ontogenesis of rabbit intestinal receptor for 1,25-dihydroxyvitamin $\mathrm{D}$-evidence for increased receptor content during late suckling and lactating periods. Comp Biochem Physiol 78A:333-336

24. Chen TL, Feldman D 1981 Regulation of 1,25 dihydroxyvitamin $\mathrm{D}_{3}$ receptors in cultured mouse bone cells: correlation of receptor concentration with the rate of cell division. J Biol Chem 256:5561-5566

25. Libermann UI, Eil C, Holst P, Rosen JF, Marx SJ 1983 Hereditary resistance to 1,25-dihydroxyvitamin $\mathrm{D}$ : defective function of receptors for 1,25-dihydroxyvitamin D in cell cultured from bone. J Clin Endocrinol Metab 57:958962

26. Feldman D, Chen T, Cone T, Hirst M, Shani S, Benduli A, Hochberg Z 1982 Vitamin D resistant rickets with alopecia: cultured skin fibroblasts exhibit defective cytoplasmic receptors and unresponsiveness to $1,25(\mathrm{OH})_{2} \mathrm{D}_{3}$. J Clin Endocrinol Metab 55:1020-1022

27. Chandler JS, Dokoh S, Pike JW, Haussler MR 1981 1,25-Dihydroxyvitamin $\mathrm{D}_{3}$-receptors and responsiveness in established cell lines from mammalian kidney, breast and pituitary. Calcif Tissue Int 33:331A(abstr)

28. Mudher S, Braidman IP, Hales M, Anderson DC 1982 Comparison of binding of 1,25-dihydroxycholecalciferol in intact tissue and cytosol preparations from bone and other tissues in the foetal rat. J Endocrinol 92:147-155 